\title{
Javanese Cultural Values in the Settlement of Kauman Yogyakarta: Its Continuity and Changes
}

\author{
Cama Juli Rianingrum ${ }^{1}$, Drajatno Widi Utomo $^{2}$, Atridia Wilastrina ${ }^{3}$ \\ \{cama.yuli@trisakti.ac.id ${ }^{1}$ \}
}

Department of Product Design Magister, Faculty of Art and Design, Universitas Trisakti, Jakarta, Indonesia $^{1}$, Department of Visual Communication Design, Faculty of Art and Design, Universitas Trisakti, Jakarta, Indonesia ${ }^{2}$, Department of Interior Design, Faculty of Art and Design, Universitas Trisakti, Jakarta, Indonesia ${ }^{3}$

\begin{abstract}
A settlement is the built environment that essentially has a close relationship as a place to live and carry out activities for a group of individuals. The Settlement of Kauman Yogyakarta is a unique and distinctive residential area with a long history of approximately 250 years. It is one of the settlements that have a soul that connects the past, present, and future. Through various cultural, political, power, and social events, from the periods of Dutch colonialism, Japanese colonialism, and the independence revolution to the government of the Republic of Indonesia, the Settlement of Kauman Yogyakarta has a special historical value in the life of the Indonesian people. There is continuity and change in the form of physical and non-physical settlements. Furthermore, from its early development to the present day, the Yogyakarta Kauman settlement has become a unique and distinctive form of settlement in the middle of the city of Yogyakarta. The type of this study was qualitative research, by describing the data, analyzing the phenomena, and presenting the results descriptively. the qualitative-descriptive analysis method aimed to describe the continuity and changes that occurred visually in the research object. Settlement structures as research objects that show continuity are represented in the orientation of the settlement area, settlement layout, building hierarchy, materials and interior layout. Based on the results of the analysis and findings in the field, the physical form of the Settlement of Kauman Yogyakarta is in a condition of continuity.
\end{abstract}

Keywords: settlement; Kauman Yogyakarta; Javanese cultural; continuity; changes

\section{Introduction}

A settlement as a residential area always has problems related to the condition of the area and the social conditions of the people who live in it culturally, psychologically, and behaviorally. The artificial environment or residence is part of cultural life, cultural expressions to convey certain messages that can also interpretation the culture of a nation or a certain period [1] [2], [3]. A settlement is the built environment that essentially has a close 
relationship as a place to live and carry out activities for a group of individuals. However, the settlements are not just built as it is. The Settlement of Kauman Yogyakarta is a unique and distinctive residential area with a long history of approximately 250 years. It is one of the settlements that have a soul that connects the past, present, and future. This settlement has a certain geographical and architectural basis, which indicates an activity context that has a cognitive identity and involves several social aspects [4].

The Settlement of Kauman Yogyakarta was built in 1775 on the orders of Sultan Hamengkubuwono I [5], [6]. At first, it is intended as a residence for administrators (abdi dalem) for the religious affairs and the palace mosque. As time goes by, this settlement was inhabited by Javanese people that were closed and bound by family ties due to endogamous marriages with education and activities that were closely related to kejawen or Javanese Islam [7], [8]. Since its inception to date, this settlement has passed through 4 periods of social, cultural, political, and religious events, namely as follows [4].

a. The period of the Kraton Yogyakarta and the colonial era. In this period, the settlement was included in the territory of the Kraton Yogyakarta socially and politically. Besides, it was also under the rule of the Dutch colonialists.

b. The period of Batik Handle. This period is characterized by the emergence and development of the batik industry in this settlement, involving the wives of abdi dalem (1880 - 1930). In addition, the contact with people outside the settlements and the palace began in this period.

c. The period of Muhammadiyah in 1912 by KH Ahmad Dahlan. This period is characterized by the emergence of a norm of religious life that leads to the purification of Islamic teachings that are different from kejawen.

d. The period of post-independence (1945 - present). In this period, there is a shift in power, political, and social aspects. Kraton Yogyakarta becomes a part of the Republic of Indonesia and then becomes a tourist and student city.

Through various cultural, political, power, and social events, from the periods of Dutch colonialism, Japanese colonialism, and the independence revolution to the government of the Republic of Indonesia, the Settlement of Kauman Yogyakarta has a special historical value in the life of the Indonesian people. The Kauman community can adapt and cope with the pressures of change, growth, development, and technological, political, economic, \& social progress. There is continuity and change in the form of physical and non-physical settlements. Furthermore, from its early development to the present day, the Yogyakarta Kauman settlement has become a unique and distinctive form of settlement in the middle of the city of Yogyakarta [8].

\section{Methods}

The type of this study was qualitative research, by describing the data, analyzing the phenomena, and presenting the results descriptively. The qualitative method is used for research on community life, social activities, meaning, and others. Qualitative research describes research procedures that produce qualitative descriptive data in the form of written or spoken words and the behavior of the people observed [9]. The approach used in this study was a historical approach and a cultural approach with an emphasis on continuity and change that took place over a period of more than two centuries. In addition, researchers also conducted observations on the environment, settlement design, architecture, and patterns of social life. In this study, the qualitative-descriptive analysis method aimed to describe the 
continuity and changes that occurred visually in the research object, in this case, the form of contemporary settlements which are motivated by traditional culture, social life, and religion which are interpreted by the residents as owners of culture.

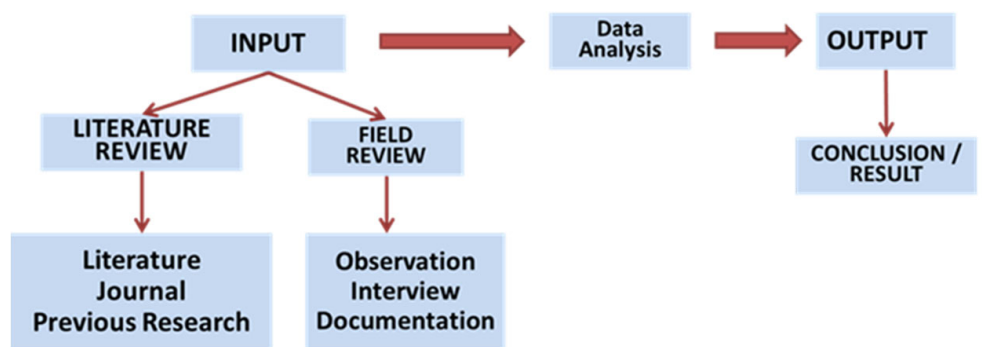

Fig. 1. Research Stages

(Source: Researchers' Documentation, 2021)

The object of research is the physical form of the settlement which is a representation of Javanese cultural values which are always obeyed and lived by the residents in the process of its realization from its inception to the present day. Several settlement structures as research objects that show continuity are represented in the orientation of the settlement area, settlement layout, building hierarchy, materials and interior layout.

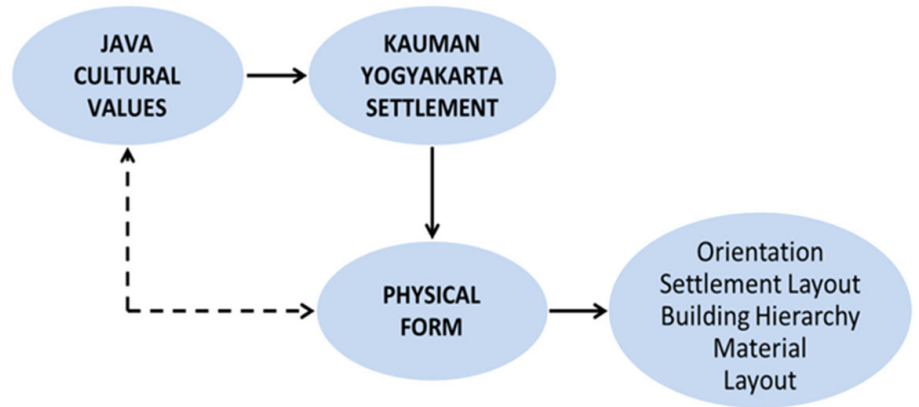

Fig. 2. Object of Research

(Source: Researchers' Documentation, 2021)

\section{Results and Discussion}

The settlement of Kauman Yogyakarta is currently located in Ngupasan, Gondomanan, Yogyakarta. This settlement area is divided into $4 \mathrm{RW}$ and $17 \mathrm{RT}$ with an area of approximately 192,000 $\mathrm{m}^{2}$ (Bappeda, 1994). 

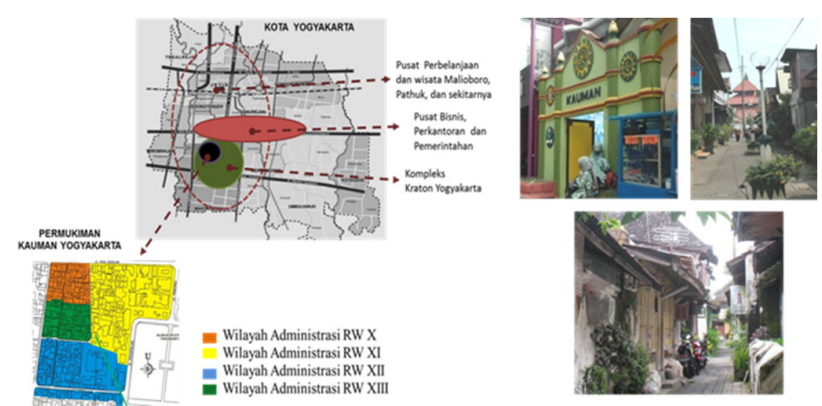

Fig. 3. The Map of the Location of Yogyakarta Kauman Settlement The entrance gate to the settlement and the atmosphere within the settlement

(Source: Bapeda Prop. DIY, 1994; Researchers' Documentation, 2015)

Indonesia is rich in traditional and unique cultures from Sabang to Merauke. Each culture has a cultural system in the form of a series of concepts contained in the mind of the owner of the culture about what is considered valuable and important in life. Cultural values have a function as the highest guideline that regulates human behavior in the form of norms, laws, customs, ethics, morals, and manners. Cultural values are directly and indirectly manifested by the actions of the community related to attitudes, behavior, speech, and others. In addition, it can be manifested in the form of cultural products. In general, cultural values can be grouped into five categories, namely (1) cultural values in human relations with God, (2) cultural values in human relations with society, (3) cultural values in human relations with other humans, (4) cultural values in human relations with himself/herself, and (5) cultural values in human relations with nature [10].

The Settlement of Kauman Yogyakarta is developed and grows for more than two centuries as a distinctive settlement that is different from other Kauman on Java Island [6], [11]. Several changes that occur as a result of social, cultural, and power shifts are presented in the following Table 1 [12].

Table 1. Social, Cultural, and Power Changes in the Yogyakarta Kauman Settlement (Source: Various sources; Researchers' documentation, 2021)

\begin{tabular}{|c|c|c|}
\hline Aspects & Pre-Independence & Post-Independence \\
\hline Institutional & Part of the bureaucracy of Kraton & Part of the bureaucracy of Yogyakarta \\
\hline position & Yogyakarta & Province and the Republic of Indonesia \\
\hline Power & $\begin{array}{l}\text { Under the rule of the Sultan of } \\
\text { Yogyakarta }\end{array}$ & Under the Republic of Indonesia \\
\hline Religion/belief & Traditional Islam/Kejawen & $\begin{array}{l}\text { Islam based on the teachings of the } \\
\text { Qur'an and As-Sunnah }\end{array}$ \\
\hline Education & $\begin{array}{l}\text { Only Islamic education with } \\
\text { Islamic boarding school system. }\end{array}$ & $\begin{array}{l}\text { Islamic education and general knowledge } \\
\text { with the public school system. }\end{array}$ \\
\hline Economy & Middle - lower & Lower - Middle - Upper \\
\hline Occupation & $\begin{array}{l}\text { Abdi dalem of the Kraton } \\
\text { Yogyakarta; Working as a batik } \\
\text { entrepreneur as a side job. }\end{array}$ & $\begin{array}{l}\text { Abdi dalem, teachers (Muhammadiyah), } \\
\text { businessmen (catering, boarding), Army, } \\
\text { civil servants, and merchants }\end{array}$ \\
\hline Status of Women & $\begin{array}{l}\text { In the field of religion and society, } \\
\text { the status of women is below men's } \\
\text { status. }\end{array}$ & $\begin{array}{l}\text { The status of women and men is the } \\
\text { same. There is tolerance in traditional } \\
\text { customs and social activities. }\end{array}$ \\
\hline $\begin{array}{l}\text { Marriage \& } \\
\text { family system }\end{array}$ & $\begin{array}{l}\text { Endogamous marriage (marriage } \\
\text { between family lines) in the }\end{array}$ & $\begin{array}{l}\text { Marriage outside the family line and } \\
\text { outside the Kauman ties. }\end{array}$ \\
\hline
\end{tabular}




\begin{tabular}{lll}
\hline \multicolumn{1}{c}{ Aspects } & \multicolumn{1}{c}{ Pre-Independence } & \multicolumn{1}{c}{ Post-Independence } \\
\hline $\begin{array}{l}\text { Territory } \\
\text { Division }\end{array}$ & $\begin{array}{l}\text { Kauman ties. } \\
\text { Divided into 2 groups, the Kauman } \\
\text { community and the Nginungan } \\
\text { community. }\end{array}$ & $\begin{array}{l}\text { Divided into 4 RWs in one area (Kauman } \\
\text { Village) }\end{array}$ \\
$\begin{array}{l}\text { Leadership } \\
\text { within the } \\
\text { settlement }\end{array}$ & $\begin{array}{l}\text { Principal of the sultanate } \\
\text { Starting in 1946, it is the Head of the }\end{array}$ & $\begin{array}{l}\text { Hamlet (Indonesia: } \text { Rukun Kampung } \\
\text { (RK) then transformed into Rukun Warga }\end{array}$ \\
People's Attitude & Closed & (RW)) \\
\hline
\end{tabular}

The values given to objects (cultural works) from humans are values or norms that are agreed upon and have been embedded in people's lives and their environment which are rooted in a belief as a basis and become a reference for behavior [13]. Two forms of culture are architecture and the residential environment which contain a system of cultural values, namely the values of functions, meanings, and symbols.

\section{a) Function}

A building must possess a soul like the breath in the human. The soul is represented in the image of the building. In other words, a building, even though it is just an inanimate object, also has a "soul" [14].

\section{b) Meaning}

Meaning appears as a result of the concept of thought which is then translated into visual language, namely forms [15]. Meaning is intersubjective because it grows and develops individually. However, the meaning can be shared, accepted, and agreed upon by all members of society.

\section{c) Symbol}

The function of symbols of the overall architectural form is to animate material signs and make them speak [16], [17]. An object is valued from its ability to provide answers and solutions to problems or challenges faced based on three principles, namely truth, goodness, and beauty.

Continuity has the meaning of preservation and regeneration of the problems faced and how to realize the solution. Therefore, in its development, it reaches what is expected. To support continuity, there needs to be an understanding and commitment of community members in realizing their expectations. Theoretically, the occurrence of continuity requires support from community members in cultural behavior and internalization of its development. To reveal the existence of continuity, it is necessary to observe the causes of change as problems in its development.

Table 2. Continuity and Changes in the Design of the Yogyakarta Kauman Settlement (Source: Researchers, 2021)

\begin{tabular}{|c|c|c|c|}
\hline Idea & $\begin{array}{c}\text { Javanese Cultural } \\
\text { Values }\end{array}$ & Settlement Design & $\begin{array}{l}\text { Analysis of Continuity } \\
\text { and Change }\end{array}$ \\
\hline
\end{tabular}




\begin{tabular}{|c|c|c|c|}
\hline Idea & $\begin{array}{c}\text { Javanese Cultural } \\
\text { Values }\end{array}$ & Settlement Design & $\begin{array}{c}\text { Analysis of Continuity } \\
\text { and Change }\end{array}$ \\
\hline $\begin{array}{l}\text { ORIENTATION } \\
\text { An imaginary line runs } \\
\text { from south to north. } \\
\text { Determination of direction } \\
\text { has the intention that the } \\
\text { people in this settlement } \\
\text { have good hopes in their } \\
\text { lives. }\end{array}$ & $\begin{array}{l}\text { Macro-Microcosmos } \\
\text { Balance (Creating and } \\
\text { maintaining harmony } \\
\text { between the natural and } \\
\text { supernatural realms) } \\
\text { The layout of } \\
\text { Yogyakarta is built } \\
\text { based on the orientation } \\
\text { of the imaginary line of } \\
\text { North and South, which } \\
\text { has the meaning of a } \\
\text { process of human life: } \\
\text { birth - life - death } \\
\text { (Sangkan - Paraning - } \\
\text { Dumadi). }\end{array}$ & $\begin{array}{l}\text { The people of Kauman } \\
\text { as Javanese people } \\
\text { believe in the cosmology } \\
\text { of the south-north axis. } \\
\text { This cosmology is a } \\
\text { reference for the } \\
\text { orientation of the } \\
\text { establishment of the } \\
\text { Kraton Yogyakarta. }\end{array}$ & $\begin{array}{l}\text { The Kauman settlement is } \\
\text { built based on the concept } \\
\text { of spatial planning in } \\
\text { Javanese cosmology. The } \\
\text { layout is made in a } \\
\text { straight line (axis) from } \\
\text { north to south which is an } \\
\text { expression of the } \\
\text { relationship between the } \\
\text { world of the macrocosm } \\
\text { and microcosm. }\end{array}$ \\
\hline $\begin{array}{l}\text { SETTLEMENT } \\
\text { LAYOUT } \\
\text { The settlement area is } \\
\text { arranged in the form of a } \\
\text { complex consisting of } \\
\text { various buildings } \\
\text { surrounded by guardrails } \\
\text { and gates. }\end{array}$ & $\begin{array}{l}\text { The gate has a symbolic } \\
\text { value, namely as a } \\
\text { symbol of different } \\
\text { levels in the } \\
\text { cosmological system, } \\
\text { and also serves as a } \\
\text { guard who has physical } \\
\text { and mental strength. } \\
\text { The yard, apart from } \\
\text { having a symbolic } \\
\text { meaning, also serves as } \\
\text { a filter against the wind, } \\
\text { dust, and solar heat. }\end{array}$ & 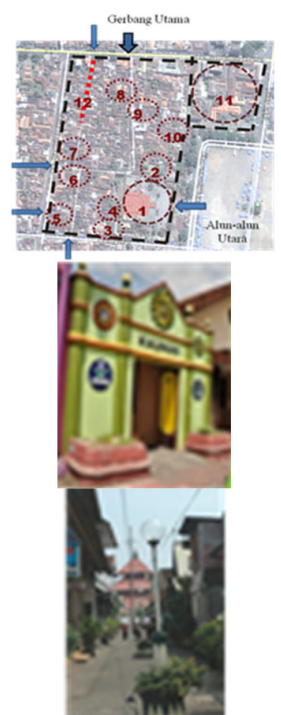 & $\begin{array}{l}\text { This settlement is limited by } \\
\text { buildings that surround the } \\
\text { settlement area, forming the } \\
\text { boundaries of the settlement } \\
\text { area like a fort wall. To } \\
\text { enter this settlement, one } \\
\text { must pass through an open } \\
\text { gate that can only be passed } \\
\text { on foot or by two-wheeled } \\
\text { vehicles. The gates are } \\
\text { connected by a road or alley } \\
\text { that forms a hallway, } \\
\text { flanked by a row of } \\
\text { buildings on both sides. }\end{array}$ \\
\hline $\begin{array}{l}\text { BUILDING } \\
\text { HIERARCHY } \\
\text { The difference in height } \\
\text { and grandeur of the } \\
\text { building }\end{array}$ & $\begin{array}{l}\text { Unggah-ungguh (Social } \\
\text { Hierarchy): The } \\
\text { buildings of ordinary } \\
\text { people should not be } \\
\text { higher than buildings } \\
\text { that are considered to } \\
\text { have spiritual value or } \\
\text { belong to people with } \\
\text { higher positions } \\
\text { because the Javanese do } \\
\text { not want bad } \\
\text { consequences due to }\end{array}$ & $\begin{array}{l}\text { Buildings in settlements } \\
\text { must follow a building } \\
\text { hierarchy with Javanese } \\
\text { cultural values, namely } \\
\text { based on social and } \\
\text { power hierarchies. }\end{array}$ & $\begin{array}{l}\text { The shape and height of } \\
\text { the mosque building are } \\
\text { the highest compared to } \\
\text { other buildings. The } \\
\text { building of ordinary } \\
\text { people should not exceed } \\
\text { the height of the ruler's } \\
\text { house and the kraton. }\end{array}$ \\
\hline
\end{tabular}




\begin{tabular}{|c|c|c|c|}
\hline Idea & $\begin{array}{c}\text { Javanese Cultural } \\
\text { Values }\end{array}$ & Settlement Design & $\begin{array}{l}\text { Analysis of Continuity } \\
\text { and Change }\end{array}$ \\
\hline & disrespect. & & \\
\hline $\begin{array}{l}\text { MATERIAL } \\
\text { The design of home with } \\
\text { environmentally friendly } \\
\text { materials. The whole } \\
\text { structure of a Javanese } \\
\text { house can be seen without a } \\
\text { cover because it looks } \\
\text { beautiful so that it does not } \\
\text { need to be hidden. In } \\
\text { addition to having a } \\
\text { functional value, it also } \\
\text { shows strength and beauty. }\end{array}$ & $\begin{array}{l}\text { Soko Guru is a } \\
\text { prominent part and is } \\
\text { considered the most } \\
\text { beautiful in a Javanese } \\
\text { house building. } \\
\text { The four main pillars } \\
\text { that support the joglo } \\
\text { roof are called Soko } \\
\text { Guru. Soko Guru has } \\
\text { the meaning of the four } \\
\text { winds as a source of } \\
\text { strength. Based on the } \\
\text { spiritual concept, its } \\
\text { intersection point is } \\
\text { also known as Pancer } \\
\text { or Manunggaling } \\
\text { Kiblat Papat. }\end{array}$ & $\begin{array}{l}\text { The open form of the } \\
\text { building has the } \\
\text { advantage of making air } \\
\text { circulation thoroughly } \\
\text { and maximally. }\end{array}$ & $\begin{array}{l}\text { The shape of the house in } \\
\text { the Kauman settlement } \\
\text { has soko guru in the } \\
\text { middle and open area. The } \\
\text { high roof structure allows } \\
\text { maximum natural air } \\
\text { circulation. Even though } \\
\text { there are insulating walls } \\
\text { on all four sides, the air } \\
\text { circulation is still maximal } \\
\text { because there are } \\
\text { ventilation holes. }\end{array}$ \\
\hline \multirow{5}{*}{$\begin{array}{l}\text { INTERIOR LAYOUT } \\
\text { The layout of the Javanese } \\
\text { house has a symmetrical } \\
\text { shape. In addition, the } \\
\text { arrangement and division of } \\
\text { space are also symmetrical. } \\
\text { The position of sentong is } \\
\text { on the right and left. } \\
\text { Besides, emper can be } \\
\text { found in the front, back, } \\
\text { left, and right of the } \\
\text { building. Usually, the } \\
\text { position of the door is in the } \\
\text { middle, while the windows } \\
\text { are positioned on its left } \\
\text { and right. }\end{array}$} & \multirow{9}{*}{$\begin{array}{l}\text { The symmetrical } \\
\text { Javanese house layout } \\
\text { shows the concept of } \\
\text { balance. It creates a } \\
\text { perception of stability } \\
\text { and balance. }\end{array}$} & \multirow{4}{*}{$\begin{array}{l}\text { The layout of this house } \\
\text { has a spatial arrangement } \\
\text { that is divided into three, } \\
\text { namely as follows. } \\
\text { Terrace (pendhapa) is } \\
\text { the front room for guests. } \\
\text { Pringgitan is the middle } \\
\text { room and a connector } \\
\text { between the front room } \\
\text { and the inner room. } \\
\text { Dalem and sentong are } \\
\text { private areas or core } \\
\text { rooms. }\end{array}$} & \multirow{9}{*}{$\begin{array}{l}\text { Although the houses have } \\
\text { been renovated, the } \\
\text { concept of spatial } \\
\text { planning in Javanese } \\
\text { architecture has not } \\
\text { disappeared completely. } \\
\text { The floor plans and layout } \\
\text { of the majority of } \\
\text { buildings in the } \\
\text { Yogyakarta Kauman } \\
\text { Settlement are the } \\
\text { processing of geometric } \\
\text { fields that form a } \\
\text { symmetrical rectangular } \\
\text { space. }\end{array}$} \\
\hline & & & \\
\hline & & & \\
\hline & & & \\
\hline & & 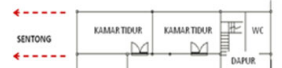 & \\
\hline 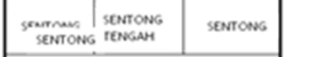 & & 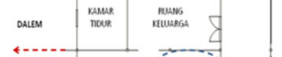 & \\
\hline DALEM & & \multirow{3}{*}{ 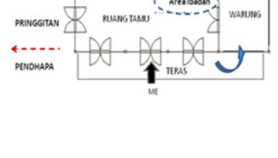 } & \\
\hline Primgatran & & & \\
\hline PEMOHAPA & & & \\
\hline
\end{tabular}


The Settlement of Kauamn Yogyakarta, in the past and then its development to the present era for approximately three centuries, has become a part of the daily life of the people of Kauman Yogyakarta which later shape the physical environment as it currently has.

\section{Conclusion}

Although Yogyakarta has become a modern city, the form of the Kauman settlement has not undergone many physical and non-physical changes. Physically, the form of settlements has not changed as seen from the arrangement of settlements and architecture. Kauman Yogyakarta grows up as a different settlement from other Kauman settlements on Java Island. Javanese society has flexibility and tolerance in accepting differences or other beliefs, because of cultural tolerance, namely the concept of unity and harmony [18], [19]. The existence of social agreement and tolerance between community members forms physical and non-physical harmony, thus forming a residential environment with a calm atmosphere that has a distinctive and unique character.

Behind the physical well-maintained settlements, it has unique background because each member of the resident community prioritizes common interests intending to live a safe, calm, and peaceful life. Based on the results of the analysis and findings in the field, the physical form of the Settlement of Kauman Yogyakarta is in a condition of continuity. The community supports continuity with an understanding and commitment to maintaining Javanese cultural values in their daily life so that the sustainability of the form of settlements is well-maintained. The Kauman settlement to date has an atmosphere like a traditional Javanese village in a closed area in the center of Yogyakarta. Its community has a simple, familial, and obedient lifestyle while carrying out Islamic religious law in their daily life. Its relations with the Yogyakarta Kraton are well maintained socially and culturally. Through 4 periods of social, cultural, religious, and power shifts, the impact of major changes only occurred in the aspects of power and religion. Shifts in social and cultural aspects have no significant impact that can cause major changes in the physical appearance of this settlement.

\section{References}

[1] A. Ronald, Nilai-nilai Arsitektur Rumah Tradisional Jawa. Yogyakarta: Gajah Mada University Press., 2005.

[2] M. Meirison, "Islamic Tolerance on Religious Freedom, Culture and Thought in Andalusia,” HIKMATUNA J. Integr. Islam. Stud., vol. 6, no. 1, pp. 63-73, 2020, doi: https://doi.org/10.28918/hikmatuna.v6i1.2313.

[3] K. R. T. S. Maharsiworo, "Islam in the Javanese Cultural Pluralism and the Keraton Performing Arts," Al-Albab, vol. 2, no. 1, pp. 51-66, 2013, doi: 10.24260/alalbab.v2i1.22.

[4] T. Suastiwi, "Pemufakatan Dan desakralisasi Ruang Di Permukiman Kauman Yogyakarta," Universitas Gajah Mada Yogyakarta, 2010.

[5] K. \& team Atmojo, Kraton Jogja: The History and Cultural Heritage. Yogyakarta: Kraton Ngayogyakarta Hadiningrat Publisher., 2004.

[6] M. Musyawaroh, T. S. Pitana, M. Masykuri, and Nandariyah, "Sustainable Revitalization in Cultural Heritage Kampong Kauman Surakarta Supported by Spatial Analysis," in IOP Conference Series: Earth and Environmental Science, 2018, vol. 
123, no. 1, doi: 10.1088/1755-1315/123/1/012043.

[7] A. Darban, "Tipologi Kampung Kauman, Yogyakarta,” Yogyakarta, 1984.

[8] A. A. Darban, Sejarah Kauman - Menguak Identitas Kampung Muhammadiyah. Yogyakarta: Surya Sarana Grafika, 2010.

[9] C. J. Rianingrum, "The Shift in Meaning Of Batik Kauman Patterns," in Art and Design, India: Novateur Publication, India, 2021, pp. 26-29.

[10] Koentjaraningrat, Kebudayaan Jawa. Jakarta: Balai Pustaka, 1994.

[11] T. S. Raffles, The History of Java. Yogyakarta: Narasi, 2008.

[12] C. J. Rianingrum, "Wujud Harmoni Budaya Jawa Pada Permukiman Kauman Yogyakarta," Institut Teknologi Bandung, 2015.

[13] F. M. Suseno, Etika Jawa: Sebuah Analisa Falsafi tentang Kebijaksanaan Hidup Jawa. Jakarta: Gramedia, 1984.

[14] Y. B. Mangunwijaya, Wastu Citra. Jakarta: PT. Gramedia Pustaka Utama, 1992.

[15] Widagdo, Desain dan Kebudayaan. Bandung: Institut Teknologi Bandung, 2005.

[16] L. Wardani, R. Soedarsono, T. Haryono, and D. Suryo, "City Heritage of Mataram Islamic Kingdom in Indonesia (Case Study of Yogyakarta Palace)," Int. J. Soc. Sci., vol. 9, no. 1, pp. 104-118, 2013, [Online]. Available: https://www.tijoss.com/9th Volume/laxmi.pdf.

[17] L. Wardani, "Interpretasi Fungsi, Makna dan Simbol Pada Interior Keraton Kilen Ngayogyakarta Handiningrat,” Institut Teknologi Bandung., 2007.

[18] S. Endraswara, Etika Hidup Orang Jawa (Pedoman Beretika dalam Menjalani Kehidupan Sehari-hari). Jakarta: Narasi, 2002.

[19] S. Endraswara, Falsafah Hidup Jawa. Tangerang: Cakrawala, 2003. 